\title{
Russian Opinion on Asbestos: All Fibers Equal
}

\author{
Sergei V. Jargin \\ Peoples' Friendship University of Russia \\ *Corresponding Author: sjargin@mail.ru
}

Copyright (C) 2013 Horizon Research Publishing All rights reserved.

\begin{abstract}
Asbestos-related health risks have been evaluated on the basis of past experience, when occupational exposures were much higher; while the linear no-threshold (LNT) approach has usually been applied. However, applicability of the LNT dose-response pattern to low levels of asbestos exposure has never been proven. Asbestos-related research has been influenced by vested interests and biases. Furthermore, current evidence does not provide sufficient support for a separate approach to serpentine (chrysotile) and amphibole asbestos by official regulations, the more so as the international trade provides for mixing of different asbestos types. Carcinogenicity and other harmful properties of different asbestos fibers, and of man-made asbestos substitutes, should be tested in large-scale animal experiments. Importantly, researchers must be independent from vested interests. In the meantime, the All Fibers Equal basis for the asbestos-related regulations would be an optimal solution. Current asbestos-related policies are irrational: asbestos production and use are banned by some countries, while others are increasing the manufacturing and exports. The rules and regulations should be internationally coordinated and revised on the basis of scientific knowledge.
\end{abstract}

Keywords Abestos, Malignant Mesothelioma, Lung Cancer

\section{Introduction}

Asbestos-related health risks have been evaluated on the basis of past experience, when occupational exposures were much higher; while it has been common to apply the linear no-threshold (LNT) approach [1]. However, applicability of the LNT dose-response pattern to low levels of asbestos exposure has never been proven [2]. Asbestos fibers may be present in the environment due to erosion of natural surface deposits [3]. Inhalation and discharge of the fibers occur normally, being in dynamic equilibrium. It can be compared to other potentially noxious factors that are present in the natural environment, for example, ionizing radiation [4-6]. Use of the LNT hypothesis to estimate risks from low radiation doses has been criticized [7]. By analogy with certain diseases after the Chernobyl accident [8] or radioactive contamination in the Urals [9], the screening effect and attribution bias were among the causes of the higher incidence of malignant mesothelioma (MM) in the populations exposed to asbestos. $\mathrm{MM}$ is an uncommon neoplasm; its diagnostic accuracy is relatively low, revisions of histopathological archives regularly detected uncertain diagnoses [10,11]. Cytogenetic studies demonstrated that $\mathrm{MM}$ is not associated with characteristic chromosomal aberrations [12-14], and accordingly is not clearly delineated as a separate entity. Together with a purposeful search for $\mathrm{MM}$ in exposed populations, it has contributed to overestimation of the incidence.

\section{Discussion}

Asbestos-related research is influenced by industrial interests and biases. Some researchers measure if any type of asbestos fiber is present in the lung or pleura, and if it is, attribute a MM to asbestos [15]. In this way, some spontaneous cases of $\mathrm{MM}$ were misclassified as asbestos-related. At the same time, it is known that MM can be spontaneous also in the presence of asbestos fiber; and etiological factors other than asbestos can play a role, including some mineral fibers, simian vacuolating virus 40 (SV40), and ionizing radiation [14,16,17]. In particular, SV40 has been discovered in animal models as an efficient co-carcinogen of asbestos in the process of mesothelioma induction [18]. Mesothelioma and brain tumors are the two tumor types most consistently associated with SV40, while the range of SV40-positivity of tumor tissue has been typically reported to be within the range 6-60\% [19]. Furthermore, SV40 is the only agent known to cause malignant transformation of human mesothelial cells in a tissue culture; whereas asbestos does not transform the cultured mesothelial cells [19]. Presence of SV40-like DNA sequences in $60 \%$ of malignant mesotheliomas, determined by PCR, western blotting, and immunohistochemistry [20], was later confirmed by other research [21,22] and a multi-institutional study [23]. After microdissection of formalin-fixed paraffin-embedded MM tissue, SV40 was detected in tumor cells but not in adjacent non-neoplastic cells [24]. It can be speculated that invasive medical 
manipulations e.g. bronchoscopy in people exposed to asbestos $[25,26]$, especially in conditions of suboptimal sterilization of instruments, could have contributed to dissemination of SV40 and other blood-borne viral infections, as it has been shown for $\mathrm{HCV}$ and GB virus $\mathrm{C}$ infection [27-29]. Some studies on asbestos and MM rely on work histories and on patients' interviews; others include interviews of friends and relatives when patients are no longer alive [15], which resulted in attribution of MM to questionable exposures in the past. Conflicts of interest related to litigation further contribute to the biases [15].

Moreover, it remains to be further clarified, what is the difference in carcinogenicity between the main asbestos types: the amphiboles (amosite, crocidolite, tremolite, anthophyllite, actinolite) and serpentines (chrysotile). The US Environmental Protection Agency (EPA) and the Agency for Toxic Substances for Disease Registry (ATSDR) deem "all fibers equal" [30]. Further unbiased research is needed to clarify the issue of fiber-specific toxicity [31]. There are data in favor of lesser potency of chrysotile as compared to the amphiboles. It was also reported that there are no significant differences in potency between the asbestos types. Some publications favoring chrysotile appear to be biased; there are also publications of questionable impartiality. Last time, the papers presumably influenced by non-scientific interests tended to become lengthier and less transparent.

It was reported that chrysotile is more rapidly cleared from pulmonary tissues than the amphiboles [32-34]. However, accumulation of the fibers in the lung is not necessarily a good indicator of their retention in pleura and thus of a carcinogenic effect. It was also reported that chrysotile accumulates preferably in the pleura $[35,36]$, probably playing a significant role in causation of MM [37]. Chrysotile was reported to be the predominant fiber type found in the pleura, while amphibole fiber prevailed in the lung, probably due to the preferential translocation of chrysotile to the pleura [38]. It was reported that there is no difference in potency between chrysotile and amosite in the MM induction; while pure crocidolite, rarely used today, was associated with a higher risk [36]. According to [39], the potency of chrysotile, crocidolite and amosite in the induction of both $\mathrm{MM}$ and lung cancer is approximately equal. Analyzing literature, it sometimes appears that earlier works on this topic were more objective than later ones.

Furthermore, admixture of tremolite to the chrysotile products can be of importance for carcinogenicity [40]. It was pointed out in the review [38] that currently available professional literature does not provide convincing evidence for the hypothesis that tremolite admixture explains for mesothelioma excess observed in studies of chrysotile-exposed workers. The topic should be clarified by independent research. The differences in potency might be predominantly related to the fibers' dimensions but not to the type of asbestos [32]. Long chrysotile fibers, used in the textile industry, were reported to be associated with a greater cancer risk than other fibers [41]. Toxicity appears to increase with the increasing fiber length [3]. At the same time, short and thin chrysotile fibers in pleural and pulmonary tissues were reported to be the most common fiber type associated with $\mathrm{MM}$ in humans [42]. Some chrysotile fibers can be stiff and brittle like those of the amphiboles, which can be associated with a higher health risk after an inhalation [40]. Furthermore, longitudinal division of chrysotile (but not of amphibole) fibers can result in formation of thin fibrils, less reliably identifiable by electron microscopy, so that the total number of the fibers would increase, possibly together with their carcinogenic potential $[43,44]$. In some animal experiments, the amphiboles and chrysotile were equally carcinogenic, also in view of the MM causation $[39,45,46]$. In vitro, chrysotile was shown to be toxic, caused chromosomal aberrations and preneoplastic transformations [39]; it was reported to be the most potent inflammatory stimulus among all asbestos types [47]. At the same time, there is evidence from epidemiological studies that chrysotile is less efficient in MM induction than the amphiboles [48,49]. Some epidemiological data favoring chrysotile have been revised at a later date [50]. Conclusions favoring chrysotile as compared to the amphiboles were made in the recent reviews $[3,51]$.

It was concluded that animal studies indicate an approximately equal risk for all asbestos fibers: "Finally, even if one accepts the argument that chrysotile asbestos does not induce mesothelioma (which we do not), the risk of lung cancer (and asbestosis) cannot be dismissed, and chrysotile appears to be just as potent a lung carcinogen as the other forms of asbestos." [38] Furthermore, according to [43], human and animal studies indicated that potency of chrysotile in view of MM causation was similar to that of the amphiboles. The same was stressed also about lung cancer $[52,53]$, which is essential because of a much higher incidence of lung cancer than that of MM. Asbestos-induced carcinogenesis is a multistep process [17]; accordingly, asbestos would have more opportunities to exert its carcinogenic effect and more targets to act upon inducing lung cancer as compared to MM, merely because the former is much more frequent than the latter.

Russia is one of the main producers and consumers of asbestos in the world. Asbestos-related diseases were thoroughly studied in the former Soviet Union. The prevailing opinion in the Russian literature has been that, if all precautions are observed, modern methods of asbestos production and processing are acceptably safe; and restrictive regulations applied by some countries are excessive [54-57]. It was concluded on the basis of a review of $3576 \mathrm{MM}$ cases that asbestos is neither a leading nor obligate causative factor [58]. Among $69 \mathrm{MM}$ cases studied in Kazakhstan, asbestos exposure was detected in no one; and geographic association of MM was found neither with asbestos mining nor with processing industry [59]. It was agreed that the concept of much higher carcinogenicity of amphiboles than that of chrysotile was not confirmed neither by own research nor by other scientists [56]. Asbestos fibers 
in drinking water and, accordingly, asbestos cement water pipes are regarded to be safe [60]. At the same time, biased statements favoring chrysotile can be found [61,62]; for example (translated from Russian): "Chrysotile fibers are easily solved and discharged." [62] Considering translocation of chrysotile fibers to pleura, discussed above, such statements are oversimplifications. Higher solubility of chrysotile was reported by in vitro studies reviewed in [3]; however, this issue should be clarified by animal experiments. Dissolution by acids does not necessarily mean easy solubility in vivo. The more rapid clearance of chrysotile fibers from lung tissues can be partly explained by the fiber splitting into thinner fibrils, less reliably identifiable by electron microscopy, and therefore partly remaining uncounted [43]. After the splitting, the fibrils can remain in the pulmonary tissue or be transferred to the pleura [37,44], continuing to exert their carcinogenic effect.

Considering the above, current evidence does not provide sufficient support for separate handling of serpentine (chrysotile) and amphibole asbestos by official regulations, the more so as the international trade provides for mixing of different asbestos types: e.g. in chrysotile products from China the levels of amphibole admixture were reported to be substantial [63]. This issue has been broadly discussed; while the influence by industrial interests was pointed out [64]. Carcinogenicity and other harmful effects of different asbestos fibers, as well as those of man-made asbestos substitutes, should be tested in large-scale animal experiments. As mentioned above, epidemiological research can be confounded by biases; therefore, the optimal approach would be chronic animal bioassays [65]. In the meantime, the All Fibers Equal basis for the asbestos-related regulations would be not only most plausible technically, but also compatible with modern knowledge, conflicting as it is.

\section{Conclusion}

The conclusion is more practical than theoretical. Today's asbestos-related research is partly influenced by industrial interests and political biases. The number of publications is growing; they become lengthier and more tangled. It is increasingly difficult to distinguish between biased and unbiased papers. Under these circumstances it is hardly possible to clarify the issue of toxicity chrysotile vs. amphiboles and, which is increasingly important today, to compare them both with the man-made fibers that are being proposed as asbestos substitutes. Therefore, it would be reasonable to adhere to the All Fibers Equal concept in formulating the policies and regulations. In conclusion, current asbestos-related policies are irrational: asbestos production and use are banned by some countries, while other countries are increasing asbestos manufacturing and exports [66,67]. The rules and regulations should be internationally coordinated and revised on the basis of scientific knowledge.

\section{REFERENCES}

[1] Case BW, Abraham JL, Meeker G, Pooley FD, Pinkerton KE. Applying definitions of "asbestos" to environmental and "low-dose" exposure levels and health effects, particularly malignant mesothelioma. Journal of Toxicology and Environmental Health. Part B, Critical Reviews, 2011;14(1-4):3-39.

[2] Gaensler EA. Asbestos exposure in buildings. Clinics in Chest Medicine, 1992;13:231-42

[3] Bernstein D, Dunnigan J, Hesterberg T, Brown R, Velasco JA, Barrera R, Hoskins J, Gibbs A. Health risk of chrysotile revisited. Critical Reviews in Toxicology, 2013;43(2):154-83.

[4] Tubiana M, Aurengo A, Averbeck D, Masse R. Recent reports on the effect of low doses of ionizing radiation and its dose-effect relationship. Radiation and Environmental Biophysics, 2006;44(4):245-51

[5] Jaworowski Z. Radiation hormesis - a remedy for fear. Human and Experimental Toxicology, 2010;29:263-70.

[6] Jargin SV. Overestimation of Chernobyl consequences: biophysical aspects. Radiation and Environmental Biophysics, 2009;48:341-4.

[7] Jaworowski Z. Observations on the Chernobyl Disaster and LNT. Dose Response, 2010;8:148-71.

[8] Jargin SV. Thyroid cancer after chernobyl: obfuscated truth. Dose Response, 2011;9:471-6.

[9] Jargin SV. On the low-dose-radiation exposure in the Techa River Cohort and mortality from circulatory diseases. Radiation and Environmental Biophysics, 2013;52:421-3.

[10] Takeshima Y, Inai K, Amatya VJ, Gemba K, Aoe K, Fujimoto N, Kato K, Kishimoto T. Accuracy of pathological diagnosis of mesothelioma cases in Japan: clinicopathological analysis of 382 cases. Lung Cancer, 2009;66:191-7.

[11] Sandeck HP, Røe OD, Kjærheim K, Willén H, Larsson E. Re-evaluation of histological diagnoses of malignant mesothelioma by immunohistochemistry. Diagnostic Pathology, 2010;5:47.

[12] Lindholm PM, Salmenkivi K, Vauhkonen H, Nicholson AG, Anttila S, Kinnula VL, Knuutila S. Gene copy number analysis in malignant pleural mesothelioma using oligonucleotide array CGH. Cytogenetic and Genome Research, 2007;119:46-52.

[13] Musti M, Kettunen E, Dragonieri S, Lindholm P, Cavone D, Serio G, Knuutila S. Cytogenetic and molecular genetic changes in malignant mesothelioma. Cancer genetics and Cytogenetics, 2006;170:9-15.

[14] Røe OD, Anderssen E, Helge E, Pettersen CH, Olsen KS, Sandeck H, Haaverstad R, Lundgren S, Larsson E. Genome-wide profile of pleural mesothelioma versus parietal and visceral pleura: the emerging gene portrait of the mesothelioma phenotype. PLoS One, 2009;4:e6554. 
[15] Yang H, Testa JR, Carbone M. Mesothelioma epidemiology, carcinogenesis, and pathogenesis. Current Treatment Options in Oncology, 2008;9:147-57.

[16] Tomasetti M, Amati M, Santarelli L, Alleva R, Neuzil J. Malignant mesothelioma: biology, diagnosis and therapeutic approaches. Current Molecular Pharmacology, 2009;2:190-206.

[17] Rascoe PA, Jupiter D, Cao X, Littlejohn JE, Smythe WR. Molecular pathogenesis of malignant mesothelioma. Expert Reviews in Molecular Medicine, 2012;14:e12.

[18] Jasani B, Gibbs A. Mesothelioma not associated with asbestos exposure. Archives of Pathology \& Laboratory Medicine, 2012;136(3):262-7.

[19] Qi F, Carbone M, Yang H, Gaudino G. Simian virus 40 transformation, malignant mesothelioma and brain tumors. Expert Reviews in Respiratory Medicine, 2011;5(5):683-97.

[20] Carbone M, Pass HI, Rizzo P, Marinetti M, Di Muzio M, Mew DJ, Levine AS, Procopio A. Simian virus 40-like DNA sequences in human pleural mesothelioma. Oncogene, 1994;9(6):1781-90.

[21] Comar M, Rizzardi C, de Zotti R, Melato M, Bovenzi M, Butel JS, Campello C. SV40 multiple tissue infection and asbestos exposure in a hyperendemic area for malignant mesothelioma. Cancer Research, 2007;67(18):8456-9.

[22] Zekri AR, Bahnassy AA, Mohamed WS, Hassan N, Abdel-Rahman AR, El-Kassem FA, Gaafar R. Evaluation of simian virus-40 as a biological prognostic factor in Egyptian patients with malignant pleural mesothelioma. Pathology International, 2007;57(8):493-501.

[23] Testa JR, Carbone M, Hirvonen A, Khalili K, Krynska B, Linnainmaa K, Pooley FD, Rizzo P, Rusch V, Xiao GH. A multi-institutional study confirms the presence and expression of simian virus 40 in human malignant mesotheliomas. Cancer Research, 1998;58(20):4505-9.

[24] Shivapurkar N, Wiethege T, Wistuba II, Salomon E, Milchgrub S, Muller KM, Churg A, Pass H, Gazdar AF. Presence of simian virus 40 sequences in malignant mesotheliomas and mesothelial cell proliferations. Journal of Cellular Biochemistry, 1999;76(2):181-8.

[25] Shi J, Mao L, Zhou SW, Chen ZD, Zhang Y, Bian LQ, Ma GY. Application of transbronchial lung biopsy in pneumoconiosis diagnosis. Zhonghua Lao Dong Wei Sheng Zhi Ye Bing Za Zhi, 2012;30(4):261-4.

[26] Gil K. Cytoimmunological changes in the bronchoalveolar lavage in asbestos exposure patients. Folia Medica Cracoviensia, 2006;47(1-4):21-36.

[27] Strickland GT. Liver disease in Egypt: hepatitis C superseded schistosomiasis as a result of iatrogenic and biological factors. Hepatology, 2006;43(5):915-22.

[28] Saludes V, Esteve M, Casas I, Ausina V, Martró E. Hepatitis $\mathrm{C}$ virus transmission during colonoscopy evidenced by phylogenetic analysis. Journal of Clinical Virology, 2013;57(3):263-266.

[29] Vanhems P, Voirin N, Trépo C, Trabaud MA, Yzèbe D, Del Signore C, et al. The risk of hospital-acquired GB virus C infection: a pilot case-control study. Journal of Hospital
Infection, 2003;53(1):72-75.

[30] Culley MR, Zorland J, Freire K. Community responses to naturally occurring asbestos: implications for public health practice. Health Education Research, 2010;25:877-91.

[31] Lenters V, Vermeulen R, Dogger S, Stayner L, Portengen , Burdorf A, Heederik D. A meta-analysis of asbestos and lung cancer: is better quality exposure assessment associated with steeper slopes of the exposure-response relationships? Environmental Health Perspectives, 2011;119:1547-55.

[32] Mossman BT, Lippmann M, Hesterberg TW, Kelsey KT, Barchowsky A, Bonner JC. Pulmonary endpoints (lung carcinomas and asbestosis) following inhalation exposure to asbestos. Journal of Toxicology and Environmental Health. Part B, Critical Reviews, 2011;14:76-121.

[33] Donaldson K, Murphy FA, Duffin R, Poland CA. Asbestos, carbon nanotubes and the pleural mesothelium: a review of the hypothesis regarding the role of long fibre retention in the parietal pleura, inflammation and mesothelioma. Particle and Fibre Toxicology, 2010;7:5.

[34] Churg A. Deposition and clearance of chrysotile asbestos. The Annals of Occupational Hygiene, 1994;38:625-33,424-5.

[35] Sebastien P, Janson X, Gaudichet A, Hirsch A, Bignon J. Asbestos retention in human respiratory tissues: comparative measurements in lung parenchyma and in parietal pleura. IARC Scientific Publications, 1980;(30):237-46.

[36] Nicholson WJ. Comparative dose-response relationships of asbestos fiber types: magnitudes and uncertainties. Annals of the New York Academy of Sciences, 1991;643:74-84.

[37] Kohyama N, Suzuki Y. Analysis of asbestos fibers in lung parenchyma, pleural plaques, and mesothelioma tissues of North American insulation workers. Annals of the New York Academy of Sciences, 1991;643:27-52.

[38] Stayner LT, Dankovic DA, Lemen RA. Occupational exposure to chrysotile asbestos and cancer risk: a review of the amphibole hypothesis. American Journal of Public Health, 1996;86:179-86.

[39] Harington JS. The carcinogenicity of chrysotile asbestos. Annals of the New York Academy of Sciences, 1991;643:465-72.

[40] Langer AM, Nolan RP. Chrysotile: its occurrence and properties as variables controlling biological effects. The Annals of Occupational Hygiene, 1994 ;38:427-51,407.

[41] Hillerdal G, Henderson DW. Asbestos, asbestosis, pleural plaques and lung cancer. Scandinavian Journal of Work, Environment \& Health, 1997;23:93-103.

[42] Suzuki Y, Yuen SR, Ashley R. Short, thin asbestos fibers contribute to the development of human malignant mesothelioma: pathological evidence. International Journal of Hygiene and Environmental Health, 2005;208:201-10.

[43] Smith AH, Wright CC. Chrysotile asbestos is the main cause of pleural mesothelioma. American Journal of Industrial Medicine, 1996;30:252-66.

[44] Coin PG, Roggli VL, Brody AR. Persistence of long, thin chrysotile asbestos fibers in the lungs of rats. Environmental Health Perspectives, 1994;102 Suppl 5:197-9. 
[45] Wagner JC, Berry G, Skidmore JW, Timbrell V. The effects of the inhalation of asbestos in rats. British Journal of Cancer, 1974;29:252-69.

[46] Wagner JC. Proceedings: Asbestos carcinogenesis. British Journal of Cancer, 1975;32:258-9.

[47] Bignon J, Jaurand MC. Biological in vitro and in vivo responses of chrysotile versus amphiboles. Environmental Health Perspectives, 1983;51:73-80.

[48] Berman DW, Crump KS. A meta-analysis of asbestos-related cancer risk that addresses fiber size and mineral type. Critical Reviews in Toxicology, 2008;38 Suppl 1:49-73.

[49] Broaddus VC, Everitt JI, Black B, Kane AB. Non-neoplastic and neoplastic pleural endpoints following fiber exposure. Journal of Toxicology and Environmental Health. Part B, Critical Reviews, 2011;14:153-78.

[50] Finkelstein MM, Meisenkothen C. Malignant mesothelioma among employees of a Connecticut factory that manufactured friction materials using chrysotile asbestos. The Annals of Occupational Hygiene, 2010;54:692-6.

[51] Kamp DW. Asbestos-induced lung diseases: an update. Translational Research, 2009;153:143-52.

[52] Berman DW, Crump KS, Chatfield EJ, Davis JM, Jones AD. The sizes, shapes, and mineralogy of asbestos structures that induce lung tumors or mesothelioma in AF/HAN rats following inhalation. Risk Analysis, 1995;15:181-95.

[53] Landrigan PJ, Nicholson WJ, Suzuki Y, Ladou J. The hazards of chrysotile asbestos: a critical review. Industrial Health 1999;37:271-80.

[54] Elovskaia LT. Anti-asbestos campaign and conference on "Asbestos and health issues". Meditsina Truda i Promyshlennaia Ekologiia, 1997;(9):16-21.

[55] Izmerov NF, Kovalevskii EV. Regulations of controlled use of asbestos-containing materials in construction industry. Meditsina Truda i Promyshlennaia Ekologiia, 2004;(5):5-12.

[56] Kogan FM. Modern concept about asbestos safety. Ekaterinburg: ARGO, 1995.
[57] Jargin SV. Asbestos and anti-asbestos campaign: in search for reasonable solutions. Ukrainian Medical Journal, published online 2013-09-12 http://m.umj.com.ua/article/65132/asbest-i-antiasbestovaya-k ampaniya-v-poiskax-razumnyx-reshenij (Russian)

[58] Kashanskii SV. Mesothelioma in Russia: systematic review of 3576 published cases from occupational medicine viewpoint. Meditsina Truda i Promyshlennaia Ekologiia, 2008;(3):15-21.

[59] Kashanskii SV, Zhetpisbaev BA, Il'derbaev OZ, Ermenbai OT. Mesothelioma in the Republic of Kazakhstan: a review. Gigiena i Sanitaria, 2008;(5):13-7.

[60] Krasovskii GN, Mozhaev EA. Asbestos in drinking water (review). Gigiena i Sanitaria, 1993;(6):20-2.

[61] Neiman SM, Vezentsev AI, Kashanskii SV. About safety of cement-asbestos materials and products. Moscow: RIF, 2006.

[62] Izmerov NF. WHO and ILO Program on elimination of asbestos-related diseases. Meditsina Truda i Promyshlennaia Ekologiia, 2008;(3):1-8.

[63] Tossavainen A, Kotilainen M, Takahashi K, Pan G, Vanhala E. Amphibole fibres in Chinese chrysotile asbestos. The Annals of Occupational Hygiene, 2001;45:145-52.

[64] Tweedale G, McCulloch J. Chrysophiles versus chrysophobes: the white asbestos controversy, 1950s-2004. Isis, 2004;95:239-59.

[65] Gwinn MR, DeVoney D, Jarabek AM, Sonawane B, Wheeler J, Weissman DN, Masten S, Thompson C. Meeting report: mode(s) of action of asbestos and related mineral fibers. Environmental Health Perspectives, 2011;119:1806-10.

[66] Brims FJ. Asbestos - a legacy and a persistent problem. Journal of the Royal Naval Medical Service, 2009;95:4-11.

[67] Collegium Ramazzini. Asbestos is still with us: repeat call for a universal ban. International Journal of Occupational Medicine and Environmental Health, 2010;23:201-7.H 